\title{
How To Design for a Tailored Subcellular Distribution of Systemic Agrochemicals in Plant Tissues
}

\author{
Hofstetter, Sandro; Beck, Andreas; Trapp, Stefan; Buchholz, Anke
}

Published in:

Journal of Agricultural and Food Chemistry

Link to article, DOI:

10.1021/acs.jafc.8b02221

Publication date:

2018

Document Version

Peer reviewed version

Link back to DTU Orbit

Citation (APA):

Hofstetter, S., Beck, A., Trapp, S., \& Buchholz, A. (2018). How To Design for a Tailored Subcellular Distribution of Systemic Agrochemicals in Plant Tissues. Journal of Agricultural and Food Chemistry, 66(33), 8687-8697. https://doi.org/10.1021/acs.jafc.8b02221

\section{General rights}

Copyright and moral rights for the publications made accessible in the public portal are retained by the authors and/or other copyright owners and it is a condition of accessing publications that users recognise and abide by the legal requirements associated with these rights.

- Users may download and print one copy of any publication from the public portal for the purpose of private study or research.

- You may not further distribute the material or use it for any profit-making activity or commercial gain

- You may freely distribute the URL identifying the publication in the public portal 
How to design for a tailored subcellular distribution of systemic agrochemicals in plant tissues

Sandro Hofstetter (1), Andreas Beck (1), Stefan Trapp (2), Anke Buchholz (1, $\left.{ }^{\star}\right)$

${ }^{1}$ Syngenta Crop Protection AG, Schaffhauserstrasse 101, 4332 Stein, Switzerland

${ }^{2}$ Technical University of Denmark, Miljoevej 113, 2800 Kongens Lyngby, Denmark

* anke.buchholz@syngenta.com, Tel +41 62866 0145, Fax +41 628660864

Running title: Predicting intracellular localization of agrochemicals in plant tissues 


\section{Abstract}

2 Foliar applied systemic agrochemicals require the entrance into the plant vascular system or

3 into specific subcellular compartments to reach their target in planta or to be imbibed by

4 piercing-sucking pests. An inappropriate subcellular localization, like accumulation of

5 aphicides in vacuoles, might lower compound efficiency due to reduced exposure to the

6 target.

7 Permeabilities and mass distributions of sixteen compounds covering a broad range of properties were measured across a pH gradient in a PAMPA ('Parallel artificial membrane permeability assay') system, providing experimental evidence for ion trapping of acids and bases in basic and acidic compartments, respectively. The results validated a predictive model which was then expanded to simulate a standardized plant cell (cytosol and vacuole) with vascular system (phloem and xylem).

This approach underlined that the absolute mass distribution across aqueous phases was defined by membrane retention $\left(M_{r}\right)$ whereas the relative mass distribution was determined by the species (neutral, acidic, basic) of compounds. These processes depend largely on $\mathrm{pK}_{\mathrm{a}}$ and $\log \mathrm{K}_{\mathrm{ow}}$ of the test compounds, which subsequently determine the partitioning of the substances in plant cell compartments. The validated model can be used as a tool in agrochemistry research to tailor the subcellular distribution by chemistry design and to interpret biology results.

Keywords:

PAMPA, intracellular localization model, $\mathrm{pH}$ partition hypothesis, vacuole trapping 


\section{Introduction}

Eukaryotic cells have highly organized subcellular compartments with distinct structural and functional features. Plant vacuoles are versatile organelles with a crucial role in osmoregulation, undertaking functions such as recycling, detoxification and storage ${ }^{14}$. Different transport processes occur at the vacuolar membrane for inorganic or biotic solutes 30. The electrochemical and $\mathrm{pH}$ gradient generated by channels and transporters might also lead to an accumulation of xenobiotics within this largest cell compartment of mature plant cells.

The present study aims to provide experimental evidence for the postulated vacuole trapping of basic pesticides in leaf cells ${ }^{10,11,34}$.

The accumulation of weakly basic compounds in acidic organelles has been observed in animal and human cells ${ }^{12,17,46,51}$ and was also recently discovered for acidic vesicles of protozoa ${ }^{20}$. Ion trapping of weakly acidic herbicides leads to phloem transport and systemic translocation in plants ${ }^{27,48}$ and is well described for phytohormones such as auxins ${ }^{21,35}$ and abscisic acid ${ }^{23}$. It is expected that a similar passive mechanism occurs in plant cells, whereby weakly basic compounds are distributed into the large acidic vacuoles. The passive accumulation of alkaloids in acidic latex vacuoles against a concentration gradient was described by Hauser and Wink (1990) ${ }^{24}$. On the macroscale, an increased accumulation of weak bases in plants was observed with increasing $\mathrm{pH}^{25,36}$. But as of yet, no systematic study on the ion trap effect due to $\mathrm{pH}$ gradients of weakly alkaline pesticides has been published.

Calculations based on first principles indicated that intrinsically very active pesticides might not show sufficient translaminar pest control which is required for a robust field performance against sucking pests after foliar spray if trapping in vacuoles inhibits dose 
effective translaminar distribution ${ }^{8}$. Especially phloem feeders such as aphids and whiteflies avoid piercing their stylet into the vacuole which contains natural plant defense compounds like alkaloids ${ }^{22}$. Lipophilic compounds may be limited in translaminar diffusive transport, as they stick to membranes and other lipophilic structures ${ }^{8}$. On the other hand, partitioning into membranes favors membrane permeation and thus symplastic transport inside mesophyll cells. Compounds accumulating inside of cells could be imbibed by cell feeders like thrips and mites. The design for specific intracellular distribution profiles may thus be seen as a new approach for target selectivity of pesticides ${ }^{7}$.

Initially we will provide experimental evidence for ion trapping of acids and bases in basic and acidic compartments, respectively. This was done by determining the permeabilities and mass distributions of diverse agrochemicals across a $\mathrm{pH}$ gradient between two differentially adjusted compartments in a 'Parallel artificial membrane permeability assay' (PAMPA). The permeabilities were measured in a kinetic and equilibrium approach.

In a second step we will compare the measured mass fractions with the postulated distributions as calculated with a cell model ${ }^{50,51}$. This model is gradually expanded to a four compartment model representing a standardized plant cell (cytosol and vacuole) and plant vascular system (phloem and xylem).

This paper provides results on a broad range of chemistry and also validates a model that allows to interpret and to predict intracellular localization. This knowledge on subcellular localization of new active ingredients in plant cells can be exploited for selective targeting of pests and is an essential element in research of modern agrochemistry.

\section{Material and Methods}


Reagents. Sixteen compounds comprising monoprotic weak acids, monoprotic weak bases and neutral compounds and differing in acid dissociation $\left(\mathrm{pK}_{\mathrm{a}}\right)$ and lipophilicity were selected for the experiments. This set of compounds included diverse chemistries including commercial agrochemicals, research compounds and the reference drug carbamazepine. The commercial insecticides pymetrozine (PYME), thiamethoxam (THMX), cyantraniliprole (CYNT), spirotetramat (SPAT) and its free acid, spirotetramat enol (SPAT enol) as well as the research compounds oxazoline (OX), imidazoline (IM) and additional research compounds (compd 1 to compd 8), which were synthesized in house. Carbamazepine (CBZ), DMSO (analytical grade), formic acid, acetonitrile (HPLC grade), methanol (HPLC grade) were obtained from Sigma-Aldrich (St Louis, MO).

The chemical structures of the compounds are shown in Figure 1. The name, abbreviation, molecular weight, $\mathrm{pK}_{\mathrm{a}}, \log \mathrm{K}_{\mathrm{ow}}$ as well as $\log \mathrm{D}$ (calculated) of test compounds are shown in Table 1. Physicochemical properties were either taken from literature or measured/calculated in-house. All weak bases had a $\mathrm{pK}_{\mathrm{a}}$ well above 7.0 whereas the weak acids possessed a pKa well below 5.5. The log $\mathrm{K}_{\mathrm{ow}}$ ranged from -0.2 to 6.8 .

The water used in this study was purified (> $18 \mathrm{M} \Omega \mathrm{cm}$ ) with Milli-Q Advantage A10 from Millipore (Merck KGaA, Darmstadt, Germany).

Parallel artificial membrane permeability assay (PAMPA). PAMPA evaluation software (PAMPA Explorer version 3.7.2) and Gutbox $^{\mathrm{TM}}$ were used from Pion (Billerica, MA). Donor plates (Multiscreen Transport Receiver Plate, MATRNPS50), acceptor plates (Multiscreen-IP, MAIPN4550, pore size $0.45 \mu \mathrm{m}$ ) and filtration plates (Multiscreen-HV, MSHVN4550, $0.45 \mu \mathrm{m}$ pore size) were purchased from Millipore (Merck KGaA, Darmstadt, Germany). Flat bottom UV-plates (reference plate) were obtained from Thermo-Fisher (Waltham, MA). Dodecane 
(reagentPlus), MES and HEPES buffer were acquired from Sigma Aldrich (St Louis, MO). L- $\alpha-$ phosphatidylcholine from egg yolk (ca. 60\%; TLC grade) from Sigma Aldrich (St Louis, MO) was not further purified and stored at $-20{ }^{\circ} \mathrm{C}$ prior to use. The phospholipid solution was prepared before usage as $10 \%(\mathrm{w} / \mathrm{v})$ phosphatidylcholine in dodecane. All test compounds were prepared as $10^{\prime} 000 \mathrm{mg} / \mathrm{L}$ stock solution in DMSO. The test solutions were further diluted with $50 \mathrm{mM}$ MES ( $\mathrm{pH} 5.5$ ) or HEPES buffer ( $\mathrm{pH} \mathrm{7.0)}$ to $50 \mathrm{mg} / \mathrm{L}$, keeping the final DMSO concentration below $1 \%(\mathrm{v} / \mathrm{v})$ and filtered through a filtration plate $(0.45 \mu \mathrm{m}$ pores $)$ prior to usage to ensure a homogenous solution.

PAMPA was performed in 96 well plates as described elsewhere ${ }^{16,32}$. The PAMPA sandwich assembly contained a donor plate and an acceptor plate creating two chambers separated by a microfilter disc (Figure 2). The filter disc was coated with $5 \mu \mathrm{L}$ of phospholipid solution and dried for $30 \mathrm{~min}$. The Tecan freedom EVO liquid handler transferred an aliquot from the test solutions into the donor plate and reference plate. The acceptor plate was prepared with acceptor buffer and the PAMPA sandwich was assembled together with the donor plate. Incubation occurred at room temperature under constant humidity in the Gut-Box ${ }^{\mathrm{TM}}$. The PAMPA sandwich was disassembled after incubation and an aliquot of both acceptor and donor solution was quantified. The compound distribution between donor, acceptor and the remaining fraction in the filter was compared to a reference sample which was directly measured after initiation of incubation.

Compounds in the permeability assay were measured under a bidirectional $\mathrm{pH}$ sink condition, initially having $\mathrm{pH} 7.0$ in the acceptor plate and $\mathrm{pH} 5.5$ in the donor plate, and following these measurements the $\mathrm{pH}$ gradients was reversed. These $\mathrm{pH}$ values were chosen to mimic an ideal plant cell simplified to two equally sized compartments, the cytosol $(\mathrm{pH} 7.0)$ and the embedded vacuole $(\mathrm{pH} 5.5)$. This gradient is more pronounced than 
common applications in pharma where the blood $(\mathrm{pH} \mathrm{7.4)}$ and small intestine $(\mathrm{pH} 6.5)$ are mimicked ${ }^{26}$. A test series generally contained DMSO as a blank and carbamazepine as an internal reference standard. Compounds were measured in triplicates in each run.

Kinetic approach. The permeability of the compounds was tested across a pH gradient from $\mathrm{pH} 7.0$ to $\mathrm{pH} 5.5$ and vice versa. The assay was done without any additional sink condition in the acceptor compartment (e.g. sodium dodecyl sulfate ${ }^{1}$ ) and performed without stirring ${ }^{3}$. The majority of investigated compounds displayed moderate hydrophobicity, i.e. $\log \mathrm{D}(\mathrm{pH}$ $5.5 / 7.0$ ) $\leq 2.5$, supposing unaffected permeability through the membrane (except compd 1, 2, 7 and 8). Inside living cells the cytosol streaming would largely eliminate unstirred boundary layers, whereas in the PAMPA system unstirred boundary layers may provide additional resistance. However, the effect of the unstirred boundary layer is minor compared to the resistance of the artificial membrane layer with a thickness of $125 \mu \mathrm{m}^{2}$, except for the highly lipophilic compounds ${ }^{9}$.

In the kinetic approach, the incubation time was $18 \mathrm{~h}$ and quantification was performed by UV spectrum (230 $-500 \mathrm{~nm})$ analysis. The effective permeability $\left(\mathrm{P}_{\mathrm{e}}\right)$ was measured by UV/Vis spectra (TECAN ${ }^{\circledR}$ infinite M200pro) and evaluated with the PAMPA evaluation software (PAMPA Explorer, Pion) ${ }^{29}$.

Equilibrium approach. In this thermodynamic approach (phase equilibrium condition), the PAMPA sandwich was incubated for six days without stirring. After this incubation period, the mass fractions in the donor and acceptor compartment were measured by UPLC (ultraperformance liquid chromatography) mass spectrometer. All other conditions were identical to the kinetic approach. During this time it is expected that equilibrium is established due to 
the small size of the system $(600 \mu \mathrm{L})$. Equilibrium for neutral compounds means identical concentrations in the donor and acceptor compartment, whereas higher concentrations are expected in the alkaline and the acidic compartment for weak acids and weak bases, respectively.

Compound concentrations were determined by UPLC-MS/UV. The UV/MS (ultraviolet / mass spectrum) signal was recorded with Agilent 1200 UPLC system (Agilent Technologies, Santa Clara, CA ) equipped with an Acquity UPLC BEH C18 $(2.1 \times 50 \mathrm{~mm}, 1.7 \mu \mathrm{m})$ column at $60^{\circ} \mathrm{C}$ (Table S1). The mobile phase consisted of (A) HPLC grade water with $0.5 \%$ methanol and $0.05 \%$ formic acid and (B) acetonitrile with $0.05 \%$ formic acid. The elution started with a mobile phase of $95 \%$ A for $12 \mathrm{~s}$ followed by a linear gradient to $100 \%$ B over $72 \mathrm{~s}$. The mobile phase was then changed gradually to $70 \% \mathrm{~B}$ for $40 \mathrm{~s}$ and returned to $5 \% \mathrm{~B}$ in the end. Peak finding and peak area quantification was performed by using XCalibur 3.0 software (Thermo Fischer Scientific).

\section{Mass distributions across donor and acceptor compartment. Compartments could be either} considered as a real biological cell compartments (an aqueous phase surrounded by a membrane) or as the bioavailability determining compartment (restriction to the aqueous phase). The latter is the case if the aqueous phase reflects the dose limiting factor to control e.g. sucking pests.

If donor and acceptor are considered as a biological cell compartment, the membrane retention $\left(M_{r}\right)$ is included in each phase. Masses in donor $\left(M_{d}\right)$ and acceptor $\left(M_{a}\right)$ were quantified and the membrane retention $\left(\mathrm{M}_{\mathrm{r}}\right)$ was derived by the mass balance; whereas $\left(M_{\text {ref }}\right)$ was the total mass in the reference plate: 
The mass fraction of donor $\left(\% \mathrm{M}_{\mathrm{d}}\right)$ was calculated as follows (Table $\left.\mathrm{S} 2\right)$ :

$171 \% M_{d}=100 \times \frac{M_{d}}{\left(M_{d}+M_{a}+M_{r}\right)}$

173 Mass fractions for acceptor $\left(\% \mathrm{M}_{\mathrm{a}}\right)$ and membrane retention $\left(\% \mathrm{M}_{\mathrm{r}}\right)$ were calculated 174 accordingly.

175 If donor and acceptor compartments were restricted to their aqueous phase, the mass 176 fraction of e.g. donor $\left(\% \mathrm{M}_{\mathrm{d}, \mathrm{aq}}\right)$ was calculated neglecting the membrane retention:

$$
\% M_{d, a q}=100 \times \frac{M_{d}}{M_{d}+M_{a}}
$$

acids and bases have two relevant molecule species that diffuse in the system, namely the neutral and the ionic species. The movement of ionized molecules across charged membranes is described by the Nernst-Planck equation ${ }^{48}$, when the electrical potential approaches zero, the equation converges to Fick's Law of diffusion. In living cells, the ATPase creates a resting potential of about $-100 \mathrm{mV}$ at the outer membrane. Artificial systems with phosphatidylcholine membranes (PAMPA) have no ATPase. A small net charge can

187 theoretically be generated due to the diffusion of buffers and electrolytic test compounds 188 across the membrane (Goldman-Hodgkin-Katz-equation ${ }^{19,45}$ ) but we do not expect this to 

208

$$
\frac{M_{a, E q}}{M_{d, E q}}=\frac{P_{e, d a}}{P_{e, a d}}
$$

have a significant effect. We therefore neglect electrical charge at the membranes and calculate with Fick's 1st Law of diffusion. Accordingly, the overall exchange across the membrane is the net exchange of both molecule species:

$$
\frac{d m}{d t}=A P_{n}\left(a_{n, d}-a_{n, a}\right)+A P_{i}\left(a_{i, d}-a_{i, a}\right)=A P_{e, d a} C_{d}-A P_{e, a d} C_{a}
$$

$\mathrm{dm} / \mathrm{dt}$ is the exchange of chemical mass from donor to acceptor, $\mathrm{A}$ is the exchange area (membrane cross-area, $\mathrm{cm}^{2}$ ), $\mathrm{P}(\mathrm{cm} / \mathrm{s})$ is permeability (of $\mathrm{n}$ neutral species and $\mathrm{i}$ ion) and $\mathrm{a}$ is chemical activity in the donor (d) and acceptor (a) compartment. $\mathrm{P}_{\mathrm{e}}$ is the effective permeability, composed of the permeability of the neutral and of the ionic species, from donor to acceptor (subscript da) or from acceptor to donor (subscript ad) compartment. For dilute aqueous solutions, activity a is approximately the same as concentration $\mathrm{C}$ in solution. The effective permeability $\mathrm{P}_{\mathrm{e}}$ depends on the individual permeabilities of the neutral or the ionic species at a given $\mathrm{pH}$. In case of steady-state, the ratio between concentrations of both compartments corresponds to the ratio of effective permeabilities. For equal volumes of donor and acceptor compartment, the concentration ratio is identical to the mass ratio, and Equation 5 follows Krämer (2016) ${ }^{28}$ :

.


211 molecule is ionized, i.e., acids at higher $\mathrm{pH}$ and bases at lower $\mathrm{pH}^{51}$. In general, ion trapping

212 only reduces $\mathrm{P}_{\mathrm{e}}$ in the direction from the compartment with trapping to the one without ${ }^{28}$.

213 In the absence of other diffusive processes, this mass ratio in steady-state equals the

214 thermodynamic phase equilibrium, i.e. the endpoint of diffusion which is the system state

215 with the highest entropy. Therefore, we determined $P_{e}$ under both trapping conditions as

216 forward permeability $\left(\mathrm{P}_{\mathrm{e}, \mathrm{fw}}\right)$ from $\mathrm{pH} 7.0$ to $\mathrm{pH} 5.5$ and as reverse permeability $\left(\mathrm{P}_{\mathrm{e}, \mathrm{rv}}\right)$ at

217 steady state (i.e. determined after 18 h) (Equation 6 and 7):

218

219 donor $\left(p H\right.$ 7.0) $\stackrel{P_{e}(f w)}{\longrightarrow}$ acceptor $(p H 5.5)$

220

221 donor $(p H 5.5) \stackrel{P_{e}(r v)}{\longrightarrow} \operatorname{acceptor}(p H 7.0)$

223 The real mass fractions in donor and acceptor compartment (i.e. in aqueous phases) at 224 equilibrium $\left(\% \mathrm{M}_{\mathrm{a}, \text { eq }}\right.$ and $\left.\% \mathrm{M}_{\mathrm{d} \text {,eq }}\right)$ are obtained by considering the membrane retention $\left(\% \mathrm{M}_{\mathrm{r}}\right)$ 225 and reflecting the different directions of permeabilities $\left(P_{e, f w}\right.$ and $\left.P_{e, r v}\right)$; as shown in Equation 2268 and 9.

227

$\% M_{a, e q}=\left(100-\% M_{r}\right) \times \frac{P_{e, f w}}{P_{e, f w}+P_{e, r v}}$

228

$$
\% M_{d, e q}=\left(100-\% M_{r}\right) \times \frac{P_{e, r v}}{P_{e, f w}+P_{e, r v}}
$$

229 Accordingly, our calculations for the relative mass distribution in donor and acceptor at 230 equilibrium were done with the membrane retention as measured in the equilibrium 
approach and with the forward and reverse permeability as measured in the kinetic

232

233

234

235

236

237

238 approach.

Cell model and adaptations. The cell model has been used for a number of applications in medicine ${ }^{46,50,51}$, and it was also coupled to transport models of pesticides in plants ${ }^{8,47}$. Here, we test and apply its core element, the model for intracellular distribution ${ }^{48}$. The chemical input parameters, log $\mathrm{K}_{\mathrm{ow}}$ neutral, $\log \mathrm{K}_{\mathrm{ow}}$ ion, $\mathrm{pK}_{\mathrm{a}}, \mathrm{MW}$ and the valency (charge number) are shown in Table 1 . The valency is +1 for bases (OX, IM and compd 3 to compd 8 ) and -1 for acids (SPAT enol, compd 1 and compd 2).

The cell model parameters were adapted to reflect the conditions in our PAMPA test system (Table S3): Only two compartments were considered (donor and acceptor). The volume of the donor (= cytosol) and the acceptor (= vacuole) were equally sized with a total volume of $600 \mu \mathrm{L}$. The applied L- $\alpha$-phosphatidylcholine concentration defined the lipid to water ratio as $0.83 \%$ to $99.17 \%$. The membrane potential was set to $0.01 \mathrm{~V}$. Equilibration started from the cytosol (donor) and the mass distribution in the cytosol and vacuole were calculated for $t=\infty$ after incubation start. The membrane retention represented the sum of both lipid fractions of both compartments, plasmalemma (cytosol) and tonoplast (vacuole).

Extension of the cell model to the four compartment model for plant tissues. A predictive model for localization of pesticides in cell compartments and transfer in plant tissues has been described recently ${ }^{8}$. Thus far, the measured or predicted mass fractions in the 'PAMPA cell model' cannot be directly translated to an in planta environment. For a direct comparison the relative dimensions of different compartments and thickness (i.e. thinner) of the biomembrane would have to be considered. These respective parameters are listed in 
Table S3. This model includes besides both major cell compartments, the cytosol (pH 7.2) and the vacuole ( $\mathrm{pH} 5.5$ ), but also both elements of the plant vascular system, the xylem ( $\mathrm{pH}$ 5.5) and phloem ( $\mathrm{pH} 8.0)$. This model approach only considered the cytosol and the vacuole as compartments containing a lipid fraction, i.e. being surrounded by the plasmalemma and tonoplast. Compounds in the lipid phase ('at lipids' fraction) or dissolved in the aqueous phase ('solved' fraction) were therefore calculated separately for each cell compartment, whereas the mass fraction in the xylem and phloem were exclusively described as the solved fraction.

\section{Results}

Kinetic measurements. The permeability measurements were done under steady state conditions (i.e. at constant kinetics) and indicated the preferred permeation direction with different $\mathrm{pH}$ gradient conditions. Neutral compounds exhibited equal permeabilities $\left(\mathrm{P}_{\mathrm{e}}\right)$ in both $\mathrm{pH}$ gradient directions (Figure 3 ) within a range of $0.19( \pm 0.01) \times 10^{-6}$ to $11.45( \pm 1.05)$ $\times 10^{-6} \mathrm{~cm} / \mathrm{s}$ (Table 2). The permeation of acidic compounds from $\mathrm{pH} 5.5$ to $\mathrm{pH} 7.0$ was in average 40 times faster than in the opposite direction. All basic compounds permeated faster from $\mathrm{pH} 7.0$ to $\mathrm{pH} 5.5$ by about factor 40; except for compd 3 which had similar permeability in both $\mathrm{pH}$ gradients. Compd 3 is the most hydrophilic compound with a log $\mathrm{D}$ of -3.6 at $\mathrm{pH}$ 5.5. Surprisingly it demonstrated very low permeability, close to the minimal detection limit in both $\mathrm{pH}$ gradient directions. Previous investigations on other basic hydrophilic compounds with bidirectional low permeabilites, proposed that ion-pair mediated transport may explain this observation ${ }^{42-44}$. The permeability of the very lipophilic compd 7 and compd 8 could not be measured. 

analysis, we had to exclude that exceptional anomalies of ionized species had affected our permeability measurements. Experimental deviation could derive e.g. from an unstirred aqueous boundary layer effect. Smolen (1973) ${ }^{41}$ demonstrated that $\mathrm{pH}$ and $\mathrm{pK}_{\mathrm{a}}$ showed the same relationship as $\log D$. Therefore we plotted the difference in $\log D$ between acidic and basic compartment $(\Delta \log D)$ and the difference of $\log \mathrm{P}_{\mathrm{e}}$ from $\mathrm{pH} 5.5$ to $\mathrm{pH} 7.0$ and vice versa $\left(\Delta \log \mathrm{P}_{\mathrm{e}}\right)$. The comparative fit with the ideal line (slope of -1 and the intercept is at zero) would validate the concept of $\mathrm{pH}$ partitioning across the membrane (Figure 4). SPAT enol, as an example, demonstrated a $\log \mathrm{P}_{\mathrm{e}}$ of -5.9 (direction $\mathrm{pH} 5.5$ to $\mathrm{pH} 7.0$ ) and $\log \mathrm{P}_{\mathrm{e}}$ of -7.4 (direction $\mathrm{pH} 7.0$ to $\mathrm{pH} 5.5$ ) resulting in a $\Delta \log \mathrm{P}_{\mathrm{e}}$ of 1.5. The corresponding $\Delta$ $\log \mathrm{D}$ was 1.5 with a $\log \mathrm{D}$ of $1.7(\mathrm{pH} 5.5)$ and $0.4(\mathrm{pH} \mathrm{7.0)}$ in the donor and acceptor compartment. Typically, neutral compounds exhibited no difference in log $D$ in buffer solutions with $\mathrm{pH} 7.0$ or $\mathrm{pH} 5.5$, resulting in no difference in log $\mathrm{P}_{\mathrm{e}}$. In contrary, most acids and bases were confronted with a $\Delta \log \mathrm{D}$ of about 1.5 which was reflected in a $\Delta \log \mathrm{P}_{\mathrm{e}}$ of 1.5 units.

Despite similar pKa as the other basic compounds, compound 3 behaved different and 295 showed similar permeabilities in both directions. This is likely due to an ion pairing mechanism which allows ion pairs to cross membranes uncharged and thus as fast as the neutral species.

Overall, we can state that the measured permeabilities of most test compounds were in good alignment with the $\mathrm{pH}$ partitioning hypothesis (Smolen 1973), which also means that the permeability of ions did not significantly contribute to the overall membrane permeability. 
Equilibrium measurements. The neutral compounds, CYNT and SPAT, exhibited equal

distribution (50:50) between donor and acceptor for both $\mathrm{pH}$ gradient directions indicating complete equilibration (Figure 5). The polar neutral compounds, PYME and THMX, showed an unequal mass balance after six days favoring the donor compartment, independent of the $\mathrm{pH}$ gradient direction. The acidic compounds, compd 1 and compd 2, were almost entirely found in the neutral compartment as reflected by the very low fractions in the acidic compartment. However, for the third acid, SPAT enol, $61 \%$ remained in the acidic compartment (Table 2) if the equilibration started from an acidic donor. Most basic compounds (OX, compd 4, compd 6, IM and compd 7) almost exclusively remained in the acidic compartment demonstrating ion trapping irrespective of the direction of the $\mathrm{pH}$ gradient. Exceptions were compd 3 (postulated ion pairing, see above), compd 5 and compd 8.

Compounds stated as not equilibrated in Table 2 showed an unexpectedly high donor fraction as e.g. for PYME and THMX. Their very low permeabilities of ca. $0.2 \times 10^{-6} \mathrm{~cm} / \mathrm{s}$ (PYME) and ca. $0.7 \times 10^{-6} \mathrm{~cm} / \mathrm{s}(\mathrm{THMX})$ indicate a very slow equilibration. Very low permeability was also observed for the acid SPAT enol $\left((1.30 \pm 0.03) \times 10^{-6} \mathrm{~cm} / \mathrm{s}\right.$ from $\mathrm{pH} 5.5$ to $\mathrm{pH} 7.0)$ and for the base compd $3\left((0.06 \pm 0.01) \times 10^{-6} \mathrm{~cm} / \mathrm{s}\right.$ from $\mathrm{pH} 7.0$ to $\left.\mathrm{pH} 5.5\right)$. These non-equilibrated compounds had a particularly low log D (Table 1).

A considerable amount of compd 5 remained in the neutral donor, when equilibrating from $\mathrm{pH} 7.0$ to $\mathrm{pH} 5.5$, which cannot be explained by a low permeability. The permeability of compd $5,(8.54 \pm 0.94) \times 10^{-6} \mathrm{~cm} / \mathrm{s}$, was in the range of other basic compounds as for instance compd 4 with $(9.58 \pm 0.48) \times 10^{-6} \mathrm{~cm} / \mathrm{s}$ and compd 6 with $(9.55 \pm 0.82) \times 10^{-6} \mathrm{~cm} / \mathrm{s}$. Almost full membrane retention was measured for compd 8 which is obviously related to its high log $\mathrm{K}_{\mathrm{ow}}$ of about 6.5 (Table 2). The equilibration from $\mathrm{pH} 7.0$ to $\mathrm{pH} 5.5$ was below the 
327 detection limit for compd 8, suggesting major compound loss during the filtration step

328 because of precipitation.

329 In general, the membrane retention at equilibrium was log $\mathrm{K}_{\text {ow }}$ dependent showing an 330 increasing membrane fraction with increasing log $\mathrm{K}_{\text {ow }}$. Assuming that measured 331 permeabilities and equilibrated mass distributions are directly related to the 332 physicochemical properties of tested compounds, the outcomes should be predictable with 333 the mathematical cell model (see Methods).

Adapted cell model predicting compound equilibration in PAMPA test system. The experimental dimension of our applied PAMPA setup had to be reflected in the cell model. In principal, the model adaptations included the equal volume of donor and acceptor, the applied $\mathrm{pH}$ conditions and a modified lipid - water distribution (Table S3). The input parameters, acid dissociation constant, lipophilicity and valency are given for each compound in Table 1.

This 'PAMPA cell model' predicted an accumulation of basic compounds in the vacuole,

342 accumulation of acidic compounds in the cytosol and equilibration for neutral compounds

343 (Figure 6 A). Increasing membrane retention was described in correspondence to increasing

$344 \log \mathrm{K}_{\mathrm{ow}}$ of test compounds.

The model predictions were compared with the mass distribution at equilibrium $\left(\% \mathrm{M}_{\mathrm{a}, \mathrm{eq}}\right.$ and $\left.\% \mathrm{M}_{\mathrm{d}, \mathrm{eq}}\right)$, which could have been taken directly from the equilibrium measurements (Table 2 ).

347 Since five compounds did not equilibrate within six days, the mass distribution at equilibrium extrapolation was done for all sixteen compounds (Figure 6 B). 
The lack of membrane retention was correctly predicted for THMX and PYME, whereas the lipid phase for the other neutral compounds was overestimated by factors of up to 1.8 (CBZ). The membrane retention was correctly predicted for acids apart from a slight overestimation for compd 2. The discrepancy between predicted and measured membrane retention was generally low except for the lipophilic IM. The full membrane retention for compd 7 and compd 8 was correctly predicted.

Predictions for the mass fraction in donor and acceptor were within a range of about $10 \%$ deviation (if overestimated lipid fraction is corrected). The only outlier was compd 3 where the measured mass balance did not fit with the prediction (probably due to postulated ionpairing).

Predicting compound distribution within a four compartment model of plant tissues. After this validation of the cell model (Figure 6) and as a core element of the 'four compartment model' the calculation of mass fractions can be extrapolated to an in planta environment. Table 3 summarizes the calculated mass fractions 'at lipids' of the vacuole and cytosol, and the solved fractions of the aqueous phase of all four standardized tissue compartments. These five fractions outline $100 \%$ of the mass balance.

This type of prediction impressively highlights PYME and THMX as excellent systemic insecticides 15,18 , with low membrane retention and highest distribution in the xylem compared to the other compounds. Acidic compounds are predicted to preferentially distribute in the cytosol and basic phloem compartment (up to 40\%). This 'phloem trapping' is well described for phytohormones ${ }^{23,35}$ and herbicides ${ }^{6}$. Basic compounds with log $\mathrm{K}_{\mathrm{ow}}<3$ were predicted to accumulate in the large, acidic vacuole. This 'vacuole trapping' was recently postulated for both basic insecticides, $\mathrm{OX}$ and $\mathrm{IM}^{8,34}$. The vacuolar fraction was 
drastically reduced with compounds having a log $\mathrm{K}_{\mathrm{ow}}>3$ by losing a considerable amount in

375 the membrane retention.

This dataset illustrates the mutual influence of log $\mathrm{K}_{\mathrm{ow}}$ and $\mathrm{pK}_{\mathrm{a}}$ on mass distributions. First, the amount distributing in the aqueous phase was highly dependent on the log D. Generally, increasing log $\mathrm{K}_{\mathrm{ow}}$ increases membrane retention. However, a separate relationship was observed for each compound species: compounds with a log $\mathrm{K}_{\text {ow }}$ of about 2.3 resulted in a membrane retention of $92 \%$ (CBZ) as neutral, of $18 \%$ (SPAT enol) as acidic and of $1 \%$ (OX) as basic species (Figure $7 \mathrm{~A}$ ). Second, the distribution within the aqueous phases revealed a $\mathrm{pK}_{a}$ dependent pattern. The predicted quantities solved in vacuoles in relation to the overall solved fractions amounted to $84-85 \%$ for neutral compounds, $8-11 \%$ for acidic compounds and $98-100 \%$ for basic compounds (Figure 7 B). This similarity in behavior of acids on the one hand and of bases on the other hand is due to the quite similar pKa-values in each group (Table 1).

Consequently, the absolute amount of a compound solved in one of the four compartments, was dictated by the membrane retention. The relative distribution across the four aqueous phases remains equal within each species of compounds (neutral, acidic, basic).

\section{Discussion}

In general, PAMPA is used to investigate kinetics of membrane permeation but not to measure equilibrium. This is even more evident when sink conditions are applied to mimic protein binding or blood flow ${ }^{4}$. However, in our context we wanted to simulate a standardized plant cell within the leaf mesophyll and we therefore assumed comparable protein levels in both compartments (i.e. neglecting protein binding). Our results obtained with the PAMPA method cannot be directly transferred to the plant cell scenario since both 
compartments, donor and acceptor, were of equal volume. In a plant cell the vacuole with about $90 \%$ takes the majority of the size. Additionally, the membrane thickness in the PAMPA system is given by the filter dimension carrying the phospholipids. This artificial membrane has a thickness of $125 \mu \mathrm{m}^{2}$ and is therefore about $20^{\prime} 000$ times thicker than a 5 to $10 \mathrm{~nm}$ thick biological lipid bilayer ${ }^{40}$. Accordingly, we would have expected the time needed to reach equilibration within the PAMPA system would be much longer than for a real biological system in situ. The relevance of thickness and lipid composition of biological membranes on solute permeability was reviewed by Shinoda $(2016)^{38}$.

The ion trap of weak electrolytes in plants is well documented, but mostly on the macroscale or organismal level. The first tests with pesticides were done by Briggs, Rigitano et al. (1987) ${ }^{5}$, where the authors demonstrated that with a series of (weakly acidic) phenoxy acetic acids, both the uptake into barley roots and the translocation to shoots depended on the $\mathrm{pH}$ of the external solution and increased with decreasing $\mathrm{pH}^{5,37}$. Later, in a study with (weakly alkaline) phenethylamines and anilines a similar effect but in the opposite direction was demonstrated ${ }^{25}$. This is due to $\mathrm{pH}$ differences between external solution and plant cells. If a chemical dissociates in the physiologically relevant range, this influences both uptake velocity and volume. Rendal, Kusk et al. (2011) ${ }^{36}$ reviewed 117 ecotoxicology results where toxicity and bioaccumulation of weak acids or bases were tested at multiple $\mathrm{pH}$ levels. Toxicity and bioconcentration factors (BCFs) increased for acids at lower $\mathrm{pH}$, the opposite was found for bases. The values of EC50 or BCF changed with $\mathrm{pH}$ when $\mathrm{pH}$ minus $\mathrm{pK}_{\mathrm{a}}$ was in the range of - 1 to 3 for acids, and - 3 to 1 for bases. According to the Henderson-Hasselbalch equation, weak acids and bases occur in both neutral and ionic species in this range, and the 
421 effect therefore can be attributed to a change of the ion trap effect. Interestingly single-

422 celled algae also show an effect of $\mathrm{pH}$ on toxicity of electrolytes ${ }^{33}$.

423

424

425

426

427

428

429

430

431

432

433

434

435

436

437

Direct in situ measurements of the concentration in acidic vacuoles are difficult due to the small size of these intracellular organelles. The authors originally attempted an experimental validation on compound localization in vacuole suspensions isolated from barley ${ }^{31}$. However, the required separation steps starting from a protoplast suspension ended many times with concentrations in vacuole fractions too close to the detection limits of test compounds (unpublished results). A recent medical study succeeded in measuring concentrations in lysosomes by using Raman scatter and found an accumulation of the weak bivalent base chloroquine more than $1^{\prime} 000$ fold ${ }^{17}$. Our results corroborate these findings. Moreover, we obtained effective permeabilities, and the permeability ratios at varying $\mathrm{pH}$ levels which are relevant for the distribution of compounds in the cytosol - vacuole system. Our results are not on the intracellular scale, but mimic those conditions. They can thus be considered as valid for the intracellular distribution in a plant cell. For this, practically no measured concentration values are available. The experimental results of our adapted PAMPA system and the model predictions are generally in very good alignment. Discrepancies were seen for: very lipophilic compounds (that can be explained with the experimental difficulties in detection of such compounds), compd 3 (postulated ion pairing) and compd 5. We can thus use this PAMPA system to obtain data that can be transferred to the intracellular level of plant leaves; and by the application of the model, we can scale-up for the transversal transfer across leaves. This information is highly relevant for the design of modern agrochemicals. Moreover, the consideration of intracellular distribution of compounds is a new and additional way to optimize for more selective plant protection 
445 products related to the mode of action and target of a given chemistry. The subcellular 446 distribution of small molecules and related cellular pharmacokinetics retain a great 447 importance in drug design ${ }^{53}$.

449 The passive permeation of small solutes across lipid membranes is a fundamental process in 450 biology. The membrane permeability of compounds is correlated to their lipophilicity (log $\left.451 \mathrm{~K}_{\mathrm{ow}}\right)$. The log $\mathrm{K}_{\mathrm{ow}}$ for drugs and agrochemicals is typically found below $5^{13}$. Agrochemicals 452 show systemic behavior (i.e. long-distance translocation within xylem or phloem) with log $453 \mathrm{~K}_{\text {ow }}$ below $3^{39}$. The mass distributions across plant cell compartments could be well 454 predicted for a broad range of agrochemicals using the presented and now validated model. This makes reference measurements in a PAMPA system obsolete if exceptions in 456 membrane permeability (e.g. ion pairing) could be excluded. Provided that active transport processes mediated through transporters or channels and metabolic transformation are 458 subordinated, the 'four compartment model' offers a great tool for chemistry design and data analysis of biology results in optimization of new agrochemical chemistries.

\section{Supporting Information description}

462 The supplement provides the measured data of the equilibrium approach (Table S1), the 463 related calculations on mass fractions (Table S2) and all parameter data for the two compartment model and the expanded four compartment model (Table S3). 
1. Acosta, E., 3 - Testing the effectiveness of nutrient delivery systems. In Delivery and Controlled Release of Bioactives in Foods and Nutraceuticals, Garti, N., Ed. Woodhead Publishing: Cambridge, England, 2008; pp 53-106.

2. Assmus, F.; Ross, A.; Fischer, H.; Seelig, J.; Seelig, A., 31P and 1H NMR Studies of the Molecular Organization of Lipids in the Parallel Artificial Membrane Permeability Assay. Mol. Pharm. 2017, 14 (1), 284-295.

3. Avdeef, A.; Bendels, S.; Di, L.; Faller, B.; Kansy, M.; Sugano, K.; Yamauchi, Y., PAMPA--critical factors for better predictions of absorption. J. Pharm. Sci. 2007, 96 (11), 2893-2909.

4. Bermejo, M.; Avdeef, A.; Ruiz, A.; Nalda, R.; Ruell, J. A.; Tsinman, O.; Gonzalez, I.; Fernandez, C.; Sanchez, G.; Garrigues, T. M.; Merino, V., PAMPA--a drug absorption in vitro model 7. Comparing rat in situ, Caco-2, and PAMPA permeability of fluoroquinolones. Eur. J. Pharm. Sci. 2004, 21 (4), 429441.

5. Briggs, G. G.; Rigitano, R. L. O.; Bromilow, R. H., Physico-chemical factors affecting uptake by roots and translocation to shoots of weak acids in barley. Pesticide Science 1987, 19 (2), 101-112. 6. Bromilow, R. H.; Chamberlain, K.; Evans, A. A., Physicochemical Aspects of Phloem Translocation of Herbicides. Weed Science 1990, 38 (3), 305-314.

7. Buchholz, A.; O'Sullivan, A. C.; Trapp, S., What Makes a Good Compound against Sucking Pests? In Discovery and Synthesis of Crop Protection Products, American Chemical Society: Washington, DC, 2015; Vol. 1204, pp 93-109.

8. Buchholz, A.; Trapp, S., How active ingredient localisation in plant tissues determines the targeted pest spectrum of different chemistries. Pest. Manag. Sci. 2016, 72 (5), 929-939.

9. Camenisch, G.; Folkers, G.; van de Waterbeemd, H., Review of theoretical passive drug absorption models: historical background, recent developments and limitations. Pharm. Acta. Helv. 1996, 71 (5), 309-327.

10. Cassayre, J.; Hüter, O.; Hughes, D.; O’Sullivan, A.; Craig, W.; Jacob, O.; Clarke, E.; Earley, F.; Schade, A., Synthesis and Insecticidal Activity of New 2-Aryl-3,5-dihydro-2H-1,4-Benzoxazepine Derivatives. In Discovery and Synthesis of Crop Protection Products, American Chemical Society: Washington, DC, 2015; Vol. 1204, pp 391-410.

11. Creemer, L. C.; Giampietro, N. C.; Lambert, W.; Yap, M. C.; deBoer, G. J.; Adelfinskaya, Y.; Castetter, S.; Wessels, F. J., Pro-insecticidal approach towards increasing in planta activity. Pest. Manag. Sci. 2017, 73 (4), 752-760.

12. De Duve, C.; De Barsy, T.; Poole, B.; Trouet, A.; Tulkens, P.; Van Hoof, F. O., Lysosomotropic agents. Biochemical Pharmacology 1974, 23 (18), 2495-2531.

13. Delaney, J.; Clarke, E.; Hughes, D.; Rice, M., Modern agrochemical research: a missed opportunity for drug discovery? Drug. Discov. Today 2006, 11 (17-18), 839-845.

14. Eisenach, C.; Francisco, R.; Martinoia, E., Plant vacuoles. Curr. Biol. 2015, 25 (4), R136-R137. 15. Elbert, A.; Haas, M.; Springer, B.; Thielert, W.; Nauen, R., Applied aspects of neonicotinoid uses in crop protection. Pest. Manag. Sci. 2008, 64 (11), 1099-1105.

16. Fischer, H.; Kansy, M.; Avdeef, A.; Senner, F., Permeation of permanently positive charged molecules through artificial membranes--influence of physico-chemical properties. Eur. J. Pharm. Sci. 2007, 31 (1), 32-42.

17. Fu, D.; Zhou, J.; Zhu, W. S.; Manley, P. W.; Wang, Y. K.; Hood, T.; Wylie, A.; Xie, X. S., Imaging the intracellular distribution of tyrosine kinase inhibitors in living cells with quantitative hyperspectral stimulated Raman scattering. Nat. Chem. 2014, 6 (7), 614-622.

18. Fuog, D.; Fergusson, S. J.; Flückiger, C., Pymetrozine: A Novel Insecticide Affecting Aphids and Whiteflies. In Insecticides with Novel Modes of Action: Mechanisms and Application, Ishaaya, I.; Degheele, D., Eds. Springer Berlin Heidelberg: Berlin, Heidelberg, 1998; pp 40-49.

19. Goldman, D. E., Potential, Impedance, and Rectification in Membranes. The Journal of General Physiology 1943, 27 (1), 37-60. 
20. Gulde, R.; Anliker, S.; Kohler, H. E.; Fenner, K., Ion Trapping of Amines in Protozoa: A Novel Removal Mechanism for Micropollutants in Activated Sludge. Environ. Sci. Technol. 2018, 52 (1), 5260.

21. Gutknecht, J.; Walter, A., Transport of auxin (indoleacetic acid) through lipid bilayer membranes. J. Membr. Biol. 1980, 56 (1), 65-72.

22. Hartmann, T.; Ober, D., Biosynthesis and Metabolism of Pyrrolizidine Alkaloids in Plants and Specialized Insect Herbivores. In Biosynthesis: Aromatic Polyketides, Isoprenoids, Alkaloids, Leeper, F. J.; Vederas, J. C., Eds. Springer Berlin Heidelberg: Berlin, Heidelberg, 2000; pp 207-243. 23. Hartung, W.; Slovik, S., Physicochemical properties of plant growth regulators and plant tissues determine their distribution and redistribution: stomatal regulation by abscisic acid in leaves. New Phytologist 1991, 119 (3), 361-382.

24. Hauser, M.-T.; Wink, M., Uptake of Alkaloids by Latex Vesicles and Isolated Mesophyll Vacuoles of Chelidonium ntajus (Papaveraceae). In Zeitschrift für Naturforschung C, 1990; Vol. 45, pp 949-957.

25. Inoue, J.; Chamberlain, K.; Bromilow, R. H., Physicochemical factors affecting the uptake by roots and translocation to shoots of amine bases in barley. Pesticide Science 1998, 54 (1), 8-21.

26. Kansy, M.; Senner, F.; Gubernator, K., Physicochemical high throughput screening: parallel artificial membrane permeation assay in the description of passive absorption processes. J. Med. Chem. 1998, 41 (7), 1007-1010.

27. Kleier, D. A., Phloem mobility of xenobiotics: I. Mathematical model unifying the weak Acid and intermediate permeability theories. Plant. Physiol. 1988, 86 (3), 803-810.

28. Krämer, S. D., Quantitative aspects of drug permeation across in vitro and in vivo barriers. Eur. J. Pharm. Sci. 2016, 87, 30-46.

29. Lumbroso, A.; Villedieu-Percheron, E.; Zurwerra, D.; Screpanti, C.; Lachia, M.; Dakas, P. Y.; Castelli, L.; Paul, V.; Wolf, H. C.; Sayer, D.; Beck, A.; Rendine, S.; Fonne-Pfister, R.; De Mesmaeker, A., Simplified strigolactams as potent analogues of strigolactones for the seed germination induction of Orobanche cumana Wallr. Pest. Manag. Sci. 2016, 72 (11), 2054-2068.

30. Martinoia, E.; Massonneau, A.; Frangne, N., Transport processes of solutes across the vacuolar membrane of higher plants. Plant. Cell Physiol. 2000, 41 (11), 1175-1186.

31. Martinoia, E.; Schramm, M. J.; Kaiser, G.; Kaiser, W. M.; Heber, U., Transport of anions in isolated barley vacuoles : I. Permeability to anions and evidence for a cl-uptake system. Plant Physiol. 1986, 80 (4), 895-901.

32. Muller, J.; Esso, K.; Dargo, G.; Konczol, A.; Balogh, G. T., Tuning the predictive capacity of the PAMPA-BBB model. Eur. J. Pharm. Sci. 2015, 79, 53-60.

33. Neuwoehner, J.; Escher, B. I., The pH-dependent toxicity of basic pharmaceuticals in the green algae Scenedesmus vacuolatus can be explained with a toxicokinetic ion-trapping model. Aquat. Toxicol. 2011, 101 (1), 266-275.

34. O'Sullivan, A. C.; Schaetzer, J. H.; Luethy, C.; Mathews, C. J.; Elliott, C.; Pitterna, T.; Pabba, J.; Jacob, O.; Buchholz, A.; Blythe, J., Synthesis and Insecticidal Activity of New Benzyl- and IndanylOxazolines, Thiazolines and Alkoxy-Alkyl-Imidazolines. In Discovery and Synthesis of Crop Protection Products, American Chemical Society: Washington, DC, 2015; Vol. 1204, pp 411-430.

35. Raven, J. A., Transport of Indoleacetic Acid in Plant Cells in Relation to $\mathrm{pH}$ and Electrical Potential Gradients, and its Significance for Polar IAA Transport. New Phytologist 1975, 74 (2), 163172.

36. Rendal, C.; Kusk, K. O.; Trapp, S., The effect of $\mathrm{pH}$ on the uptake and toxicity of the bivalent weak base chloroquine tested on Salix viminalis and Daphnia magna. Environ. Toxicol. Chem. 2011, 30 (2), 354-359.

37. Rigitano, R. L. O.; Bromilow, R. H.; Briggs, G. G.; Chamberlain, K., Phloem translocation of weak acids in ricinus communis. Pesticide Science 1987, 19 (2), 113-133.

38. Shinoda, W., Permeability across lipid membranes. Biochimica et Biophysica Acta (BBA) Biomembranes 2016, 1858 (10), 2254-2265. 
39. Sicbaldi, F.; Attilio Sacchi, G.; Trevisan, M.; A. M. Del Re, A., Root Uptake and Xylem Translocation of Pesticides from Different Chemical Classes. 1997; Vol. 50, p 111-119.

40. Sitte, P., Die Zelle in der Evolution des Lebens. In Studium generale: Auf dem Weg zu einem allgemeinen Teil der Wissenschaften, Saner, L., Ed. Springer Fachmedien Wiesbaden: Wiesbaden, 2014; pp 137-146.

41. Smolen, V. F., Misconceptions and thermodynamic untenability of deviations from $\mathrm{pH}$ partition hypothesis. J. Pharm. Sci. 1973, 62 (1), 77-79.

42. Sugano, K.; Nabuchi, Y.; Machida, M.; Asoh, Y., Permeation characteristics of a hydrophilic basic compound across a bio-mimetic artificial membrane. Int. J. Pharm. 2004, 275 (1-2), 271-278. 43. Takagi, M.; Taki, Y.; Sakane, T.; Nadai, T.; Sezaki, H.; Oku, N.; Yamashita, S., A new interpretation of salicylic acid transport across the lipid bilayer: implications of $\mathrm{pH}$-dependent but not carrier-mediated absorption from the gastrointestinal tract. J. Pharmacol. Exp. Ther. 1998, 285 (3), $1175-1180$.

44. Teksin, Z. S.; Hom, K.; Balakrishnan, A.; Polli, J. E., Ion pair-mediated transport of metoprolol across a three lipid-component PAMPA system. J Control Release 2006, 116 (1), 50-57.

45. Teorell, T., Transport processes in membranes in relation to the nerve mechanism. Exp Cell Res 1958, 14 (Suppl 5), 83-100.

46. Tischbirek, C. H.; Wenzel, E. M.; Zheng, F.; Huth, T.; Amato, D.; Trapp, S.; Denker, A.; Welzel, O.; Lueke, K.; Svetlitchny, A.; Rauh, M.; Deusser, J.; Schwab, A.; Rizzoli, S. O.; Henkel, A. W.; Muller, C. P.; Alzheimer, C.; Kornhuber, J.; Groemer, T. W., Use-dependent inhibition of synaptic transmission by the secretion of intravesicularly accumulated antipsychotic drugs. Neuron 2012, 74 (5), 830-844. 47. Trapp, S., Bioaccumulation of Polar and Ionizable Compounds in Plants. In Ecotoxicology Modeling, Devillers, J., Ed. Springer: Boston, MA, 2009; pp 299-353.

48. Trapp, S., Plant uptake and transport models for neutral and ionic chemicals. Environ. Sci. Pollut. Res. Int. 2004, 11 (1), 33-39.

49. Trapp, S.; Franco, A.; Mackay, D., Activity-based concept for transport and partitioning of ionizing organics. Environ. Sci. Technol. 2010, 44 (16), 6123-6129.

50. Trapp, S.; Horobin, R. W., A predictive model for the selective accumulation of chemicals in tumor cells. Eur. Biophys. J. 2005, 34 (7), 959-966.

51. Trapp, S.; Rosania, G. R.; Horobin, R. W.; Kornhuber, J., Quantitative modeling of selective lysosomal targeting for drug design. Eur. Biophys. J. 2008, 37 (8), 1317-1328.

52. Yang, Y.-Y.; Toor, G. S.; Williams, C. F., Pharmaceuticals and organochlorine pesticides in sediments of an urban river in Florida, USA. J. of Soils and Sediments 2015, 15 (4), 993-1004. 53. Zheng, N.; Tsai, H. N.; Zhang, X.; Rosania, G. R., The Subcellular Distribution of Small Molecules: From Pharmacokinetics to Synthetic Biology. Molecular Pharmaceutics 2011, 8 (5), 16191628. 
Table 1. Physiochemical properties with compound abbreviation, molecular weight (MW),

with calculated $\log \mathrm{K}_{\mathrm{ow}}$ ion and valency.

\begin{tabular}{|c|c|c|c|c|c|c|c|c|c|c|}
\hline & \multirow[b]{2}{*}{ compound } & \multirow[b]{2}{*}{ abbr. } & \multicolumn{6}{|c|}{ chemical properties } & \multicolumn{2}{|c|}{ model input } \\
\hline & & & $\begin{array}{c}\text { MW } \\
\text { (g/mol) }\end{array}$ & $\begin{array}{l}\mathrm{pK}_{\mathrm{a}}{ }^{a} \\
\text { (base) }\end{array}$ & $\begin{array}{l}\mathrm{pK}_{\mathrm{a}}^{\mathrm{a}} \\
\text { (acid) }\end{array}$ & $\begin{array}{l}\log K_{\text {ow }} \\
\text { neutral }\end{array}$ & $\begin{array}{c}\log D \\
(p H 5.5)\end{array}$ & $\begin{array}{c}\log D \\
(\mathrm{pH} 7.0)\end{array}$ & $\underset{\text { ion }^{b}}{\log K_{\text {ow }}}$ & Valency $^{c}$ \\
\hline \multirow[t]{5}{*}{ neutral } & Pymetrozine & PYME & 217 & 4.1 & & -0.2 & -0.2 & -0.2 & -3.7 & 1 \\
\hline & Thiamethoxam & THMX & 292 & - & & -0.1 & no $\mathrm{pK}_{\mathrm{a}}$ & no $\mathrm{pK}_{\mathrm{a}}$ & -3.6 & 1 \\
\hline & Cyantraniliprole & CYNT & 474 & & 9.1 & 1.9 & 1.9 & 1.9 & -1.6 & -1 \\
\hline & Carbamazepine & $\mathrm{CBZ}$ & 236 & & 13.9 & 2.3 & 2.3 & 2.3 & -1.3 & -1 \\
\hline & Spirotetramat & SPAT & 373 & & 10.7 & 2.5 & 2.5 & 2.5 & -1.0 & -1 \\
\hline \multirow[t]{3}{*}{ acidic } & Spirotetramat enol & SPAT enol & 301 & & 5.2 & 2.2 & 1.7 & 0.4 & -1.3 & -1 \\
\hline & Compound 1 & compd 1 & 413 & & 5.1 & 3.2 & 2.7 & 1.3 & -0.3 & -1 \\
\hline & Compound 2 & compd 2 & 516 & & 5.1 & 4.4 & 3.9 & 2.5 & 0.9 & -1 \\
\hline \multirow[t]{8}{*}{ basic } & Compound 3 & compd 3 & 272 & 9.4 & & 0.3 & -3.1 & -2.1 & -3.2 & 1 \\
\hline & Oxazoline & OX & 220 & 8.7 & & 2.3 & -0.7 & 0.6 & -1.2 & 1 \\
\hline & Compound 4 & compd 4 & 211 & 9.1 & & 2.4 & -0.8 & 0.3 & -1.1 & 1 \\
\hline & Compound 5 & compd 5 & 235 & 9.6 & & 2.6 & -0.8 & 0.1 & -0.9 & 1 \\
\hline & Compound 6 & compd 6 & 237 & 9.6 & & 3.3 & -0.1 & 0.8 & -0.2 & 1 \\
\hline & Imidazoline & IM & 300 & 9.4 & & 4.3 & 0.9 & 1.9 & 0.8 & 1 \\
\hline & Compound 7 & compd 7 & 496 & 7.9 & & 6.3 & 3.9 & 5.3 & 2.4 & 1 \\
\hline & Compound 8 & compd 8 & 513 & 7.9 & & 6.8 & 4.4 & 5.8 & 0.4 & 1 \\
\hline
\end{tabular}

$607{ }^{\mathrm{a}} \mathrm{pK}_{\mathrm{a}}$ values of PYME, THMX, CYNT, SPAT, SPAT enol, OX, IM were taken from Buchholz and Trapp (2016) ${ }^{8}$; CBZ was

608 taken from Yang (2015) ${ }^{52}$; research compounds were taken from Syngenta internal data base

$609{ }^{\mathrm{b}} \log \mathrm{K}_{\mathrm{ow}}$ neutral = $\log \mathrm{K}_{\mathrm{ow}}$ ion +3.5 from Trapp (2005) ${ }^{50}$

$610{ }^{\mathrm{c}} \mathrm{z}$ is the electric charge (synonym valency, for acids - , for bases + ) ${ }^{50}$ 
611 Table 2. Kinetic and equilibrium measurements with the $\mathrm{pH}$ gradient conditions $\mathrm{pH} 7.0$ to

$612 \mathrm{pH} 5.5$ and $\mathrm{pH} 5.5$ to $\mathrm{pH}$ 7.0. $\mathrm{P}_{\mathrm{e}}=$ effective permeability, $\mathrm{M}_{\mathrm{d}}=$ Mass fraction in donor, $\mathrm{M}_{\mathrm{a}}=$

613 Mass fraction in acceptor, ND = not determined, N/A = not analyzed (below limit of

614 detection, LOD). Compounds with a difference between $M_{a}$ and $M_{d}$ of $\geq 15 \%$ were marked

615 with "not equilibrated".

\begin{tabular}{|c|c|c|c|c|c|c|c|c|}
\hline & \multirow{4}{*}{ compound } & \multicolumn{3}{|c|}{ pH 7.0 to pH 5.5} & \multicolumn{3}{|c|}{ pH 5.5 to $\mathrm{pH} 7.0$} & \multirow{4}{*}{$\begin{array}{l}\text { comment } \\
\text { equil. meas. }\end{array}$} \\
\hline & & \multirow{3}{*}{$\begin{array}{c}\text { kinetic } \\
P_{e} \\
\left(10^{-6} \mathrm{~cm} / \mathrm{s}\right)\end{array}$} & \multicolumn{2}{|c|}{ equilibrium } & \multirow{3}{*}{$\begin{array}{c}\text { kinetic } \\
P_{\mathrm{e}} \\
\left(10^{-6} \mathrm{~cm} / \mathrm{s}\right)\end{array}$} & \multicolumn{2}{|c|}{ equilibrium } & \\
\hline & & & $\mathbf{M}_{\mathrm{a}}$ & $\mathrm{Mr}_{\mathrm{r}}$ & & $M_{d}$ & $M_{r}$ & \\
\hline & & & (\%) & (\%) & & (\%) & (\%) & \\
\hline \multirow[t]{5}{*}{ neutral } & Pymetrozine & $0.19 \pm 0.05$ & $14 \pm 2.2$ & $0.0 \pm 0.0$ & $0.19 \pm 0.01$ & $78 \pm 4.9$ & $9.0 \pm 4.9$ & not equilibrated \\
\hline & Thiamethoxam & $0.66 \pm 0.13$ & $28 \pm 1.8$ & $2.0 \pm 1.8$ & $0.65 \pm 0.06$ & $72 \pm 2.3$ & $1.0 \pm 2.1$ & not equilibrated \\
\hline & Cyantraniliprole & $7.81 \pm 1.06$ & $42 \pm 2.1$ & $17 \pm 5.1$ & $7.41 \pm 0.19$ & $40 \pm 1.2$ & $22 \pm 2.2$ & \\
\hline & Carbamazepine & $8.82 \pm 1.11$ & $\mathrm{~N} / \mathrm{A}$ & $\mathrm{N} / \mathrm{A}$ & $8.55 \pm 0.35$ & N/A & N/A & \\
\hline & Spirotetramat & $7.45 \pm 1.34$ & $26 \pm 0.1$ & $48 \pm 1.4$ & $11.45 \pm 1.05$ & $27 \pm 0.6$ & $50 \pm 1.2$ & \\
\hline \multirow[t]{3}{*}{ acidic } & Spirotetramat enol & $0.05 \pm 0.01$ & $2.0 \pm 1.6$ & $4.0 \pm 1.5$ & $1.30 \pm 0.03$ & $61 \pm 5.0$ & $2.0 \pm 4.0$ & not equilibrated \\
\hline & Compound 1 & $0.18 \pm 0.03$ & $6.0 \pm 1.7$ & $0.0 \pm 0.0$ & $7.22 \pm 0.25$ & $10 \pm 0.3$ & $16 \pm 0.9$ & \\
\hline & Compound 2 & $0.43 \pm 0.05$ & $2.0 \pm 2.9$ & $56 \pm 4.2$ & $23.20 \pm 1.81$ & $2.0 \pm 0.1$ & $64 \pm 0.7$ & \\
\hline \multirow[t]{8}{*}{ basic } & Compound 3 & $0.06 \pm 0.01$ & $8.0 \pm 8.8$ & $16 \pm 7.2$ & $0.05 \pm 0.00$ & $98 \pm 3.1$ & $1.0 \pm 2.4$ & not equilibrated \\
\hline & Oxazoline & $17.94 \pm 4.49$ & $85 \pm 0.6$ & $11 \pm 10.6$ & $0.58 \pm 0.09$ & $89 \pm 2.5$ & $4.0 \pm 3.2$ & \\
\hline & Compound 4 & $9.58 \pm 0.48$ & $81 \pm 0.6$ & $12 \pm 1.5$ & $0.32 \pm 0.02$ & $93 \pm 6.9$ & $3.0 \pm 4.2$ & \\
\hline & Compound 5 & $8.54 \pm 0.94$ & $46 \pm 0.6$ & $4.0 \pm 4.2$ & $0.45 \pm 0.12$ & $100 \pm 0.0$ & $0.0 \pm 0.0$ & not equilibrated \\
\hline & Compound 6 & $9.55 \pm 0.82$ & $78 \pm 0.5$ & $17 \pm 1.1$ & $0.38 \pm 0.02$ & $89 \pm 2.0$ & $5.0 \pm 4.0$ & \\
\hline & Imidazoline & $42.46 \pm 4.38$ & $52 \pm 0.2$ & $45 \pm 0.6$ & $0.42 \pm 0.07$ & $62 \pm 9.8$ & $35 \pm 10.2$ & \\
\hline & Compound 7 & N/A & $2.0 \pm 0.0$ & $98 \pm 2.9$ & $\mathrm{~N} / \mathrm{A}$ & $3.0 \pm 0.4$ & $97 \pm 0.4$ & \\
\hline & Compound 8 & $\mathrm{~N} / \mathrm{A}$ & ND & ND & N/A & $0.0 \pm 0.0$ & $100 \pm 0.0$ & \\
\hline
\end{tabular}

616 
617 Table 3. Calculated membrane retention ('at lipid' fractions of cytosol and vacuole) and mass

618 fractions of aqueous phases in four compartments (solved fraction of phloem, xylem, cytosol

619 and vacuole). The amount of compound solved in vacuoles in relation to the overall dissolved

620 fractions is denoted in brackets. Log $\mathrm{K}_{\mathrm{OW}}$ of neutral species is given.

\begin{tabular}{|c|c|c|c|c|c|c|c|}
\hline & \multirow[b]{2}{*}{ compound } & \multirow{2}{*}{\multicolumn{2}{|c|}{$\begin{array}{c}\begin{array}{c}\text { 'at lipids' } \\
\text { (vac + cyt) }\end{array} \\
\% \mathrm{M}_{\mathrm{r}}\end{array}$}} & \multirow[b]{2}{*}{$\% \mathrm{M}_{\text {phloem }}$} & \multicolumn{3}{|c|}{$\begin{array}{c}\text { solved fractions } \\
\text { (aqueous phases of given compartment) }\end{array}$} \\
\hline & & & & & $\% \mathrm{M}_{\text {xylem }}$ & $\% \mathrm{M}_{\text {cytosol }}$ & $\% \mathrm{M}_{\text {vacuole }}$ \\
\hline \multirow[t]{5}{*}{ neutral } & Pymetrozine & -0.2 & 3.3 & 2.2 & 2.8 & 9.6 & $82.1(85 \%)$ \\
\hline & Thiamethoxam & -0.1 & 4.3 & 2.3 & 2.8 & 10.1 & $80.5(84 \%)$ \\
\hline & Cyantraniliprole & 1.9 & 84.0 & 0.4 & 0.5 & 1.7 & $13.4(84 \%)$ \\
\hline & Carbamazepine & 2.3 & 91.5 & 0.2 & 0.2 & 0.9 & $7.1(85 \%)$ \\
\hline & Spirotetramat & 2.5 & 95.2 & 0.1 & 0.1 & 0.5 & $4.1(85 \%)$ \\
\hline \multirow[t]{3}{*}{ acidic } & Spirotetramat enol & 2.2 & 18.2 & 43.0 & 0.2 & 31.8 & $6.9(8 \%)$ \\
\hline & Compound 1 & 3.2 & 67.4 & 16.7 & 0.1 & 13.1 & $2.7(8 \%)$ \\
\hline & Compound 2 & 4.4 & 97.3 & 1.2 & 0.0 & 1.3 & $0.3(11 \%)$ \\
\hline \multirow[t]{8}{*}{ basic } & Compound 3 & 0.3 & 0.0 & 0.0 & 0.9 & 1.1 & $98(98 \%)$ \\
\hline & Oxazoline & 2.3 & 1.1 & 0.0 & 1.1 & 0.4 & $97.3(98 \%)$ \\
\hline & Compound 4 & 2.4 & 0.9 & 0.0 & 0.9 & 0.7 & $97.6(98 \%)$ \\
\hline & Compound 5 & 2.6 & 1.0 & 0.1 & 0.7 & 1.6 & $96.7(98 \%)$ \\
\hline & Compound 6 & 3.3 & 5.3 & 0.1 & 0.3 & 1.5 & $92.8(98 \%)$ \\
\hline & Imidazoline & 4.3 & 35.1 & 0.0 & 0.0 & 0.7 & 64.1 (99\%) \\
\hline & Compound 7 & 6.3 & 99.7 & 0.0 & 0.0 & 0.0 & $0.3(100 \%)$ \\
\hline & Compound 8 & 6.8 & 99.9 & 0.0 & 0.0 & 0.0 & $0.1(100 \%)$ \\
\hline
\end{tabular}

621 
622

623

624

625

626

627

628

629

630

631

632

633

634

635

636

637

638

639

640

641

642

643

644

645

Figure 1. Structures of tested agrochemicals, drugs and research compounds.

Figure 2. Schematic illustration of the compound diffusion from the donor to the acceptor compartment (Volume 50:50) in a pH gradient with buffer A and buffer B.

Figure 3. Effective permeabilities $\left(\mathrm{P}_{\mathrm{e}}\right)$ measured from $\mathrm{pH} 7.0$ to $\mathrm{pH} 5.5$ and $\mathrm{pH} 5.5$ to $\mathrm{pH} 7.0$ in the kinetic PAMPA approach (18 h). The error bars represent the standard sample deviation.

Figure 4. Correlation between the difference of $\log \mathrm{D}$ between donor and acceptor compartment $(\Delta \log \mathrm{D})$ and the difference of $\log \mathrm{P}_{\mathrm{e}}$ from $\mathrm{pH} 5.5$ to $\mathrm{pH} 7.0$ and vice versa $\left(\Delta \log \mathrm{P}_{\mathrm{e}}\right)$ measured in the kinetic approach.

Figure 5. Figure 5. Mass fractions of the aqueous phase in the acidic compartment ( $\mathrm{pH}$ 5.5) after thermodynamic equilibration. This means the mass fractions are given without the membrane retention (see Equation 3) in donor $\left(\mathrm{M}_{\mathrm{d}, \mathrm{aq}}\right)$ and acceptor $\left(\mathrm{M}_{\mathrm{a}, \mathrm{aq}}\right)$ in $\mathrm{pH}$ gradient direction from $\mathrm{pH} 5.5$ to $\mathrm{pH} 7.0$ and $\mathrm{pH} 7.0$ to $\mathrm{pH}$ 5.5, respectively. The dotted lines represent the average mass fraction of compound species in the acidic compartment: neutral 51\%, acidic $15 \%$ and basic $86 \%$. Not equilibrated compounds are marked with an asterisk. The error bars represent the standard sample deviation.

Figure 6. Mass fractions at equilibrium for donor $\left(\mathrm{M}_{\mathrm{d}}\right)$, acceptor $\left(\mathrm{M}_{\mathrm{a}}\right)$ and membrane retention $\left(\mathrm{M}_{\mathrm{r}}\right)$. (A) Mass fractions calculated with the 'PAMPA cell model'. (B) Mass distributions measured with PAMPA (see Method). 
647 Figure 7. Impact of $\log \mathrm{K}_{\mathrm{ow}}$ and $\mathrm{pK} \mathrm{K}_{\mathrm{a}}$ on mass distributions in 'at lipids' and in solved 648 fractions (Table 3). (A) Correlation between $\log \mathrm{K}_{\mathrm{ow}}$ and membrane retention related to 649 compound species. The dotted lines represent the membrane retention tendency for each 650 compound species. (B) Correlation between $\log \mathrm{K}_{\mathrm{ow}}$ and mass fraction in vacuoles relative to 651 total aqueous phase for each compound species. The dotted lines represent the average for 652 each compound species.

653 


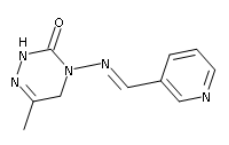

Pymetrozine

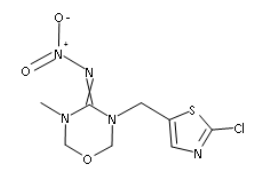

Thiamethoxam

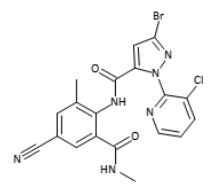

Cynantraniliprole

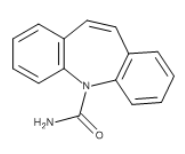

Carbamazepine

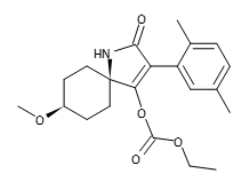

Spirotetramat

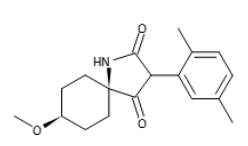

Spirotetramat eno

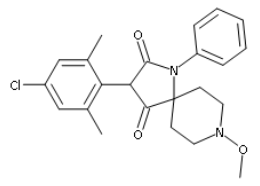

Compound 1

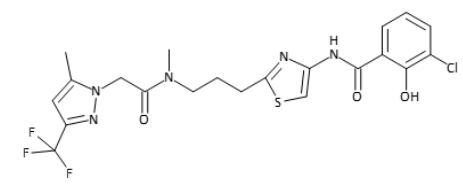

Compound 2

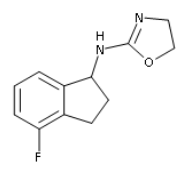

Oxazoline

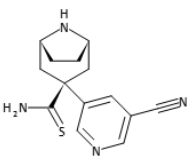

Compound 3

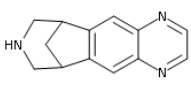

Compound 4

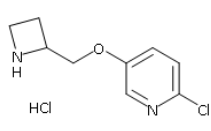

Compound 5

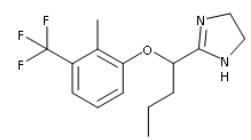

Imidazoline

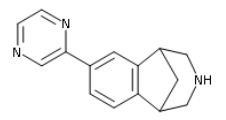

Compound 6

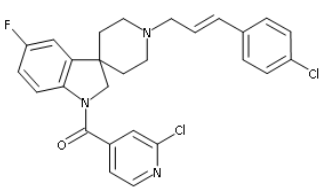

Compound 7

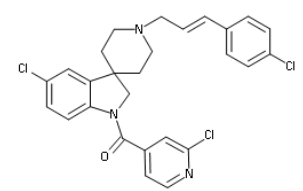

Compound 8

Figure 1. 


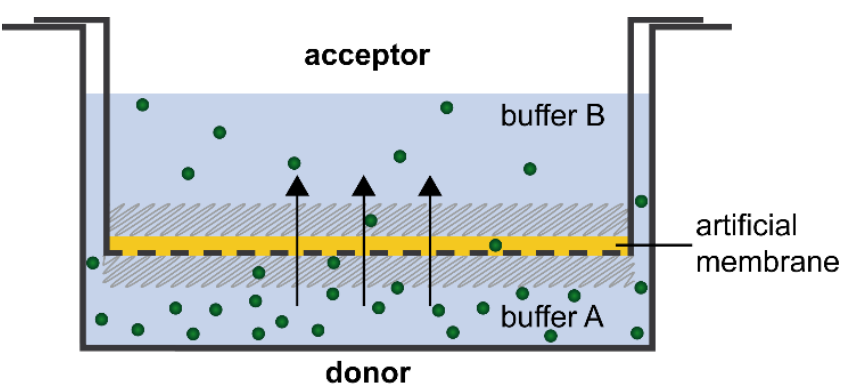

Figure 2. 


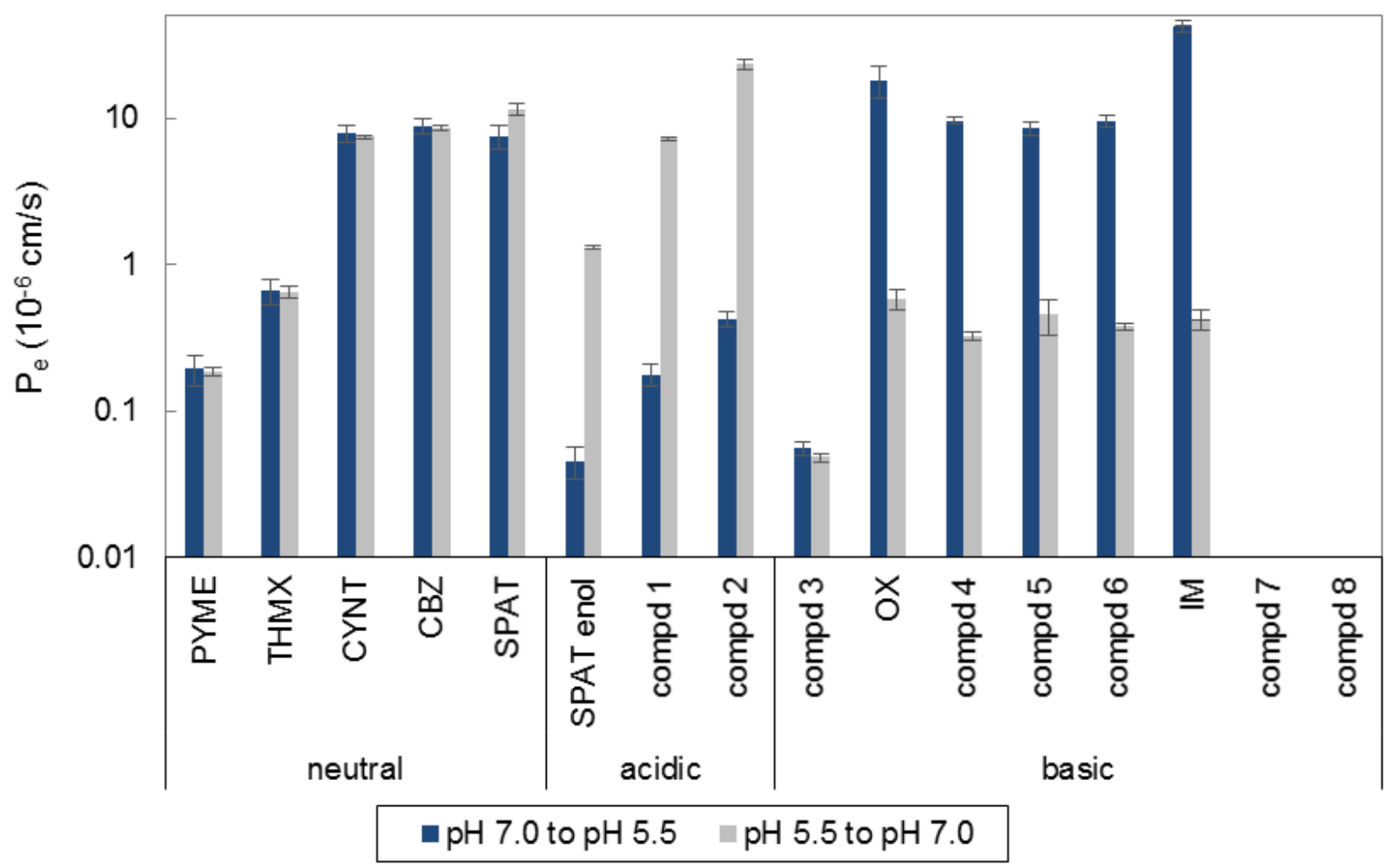

Figure 3. 


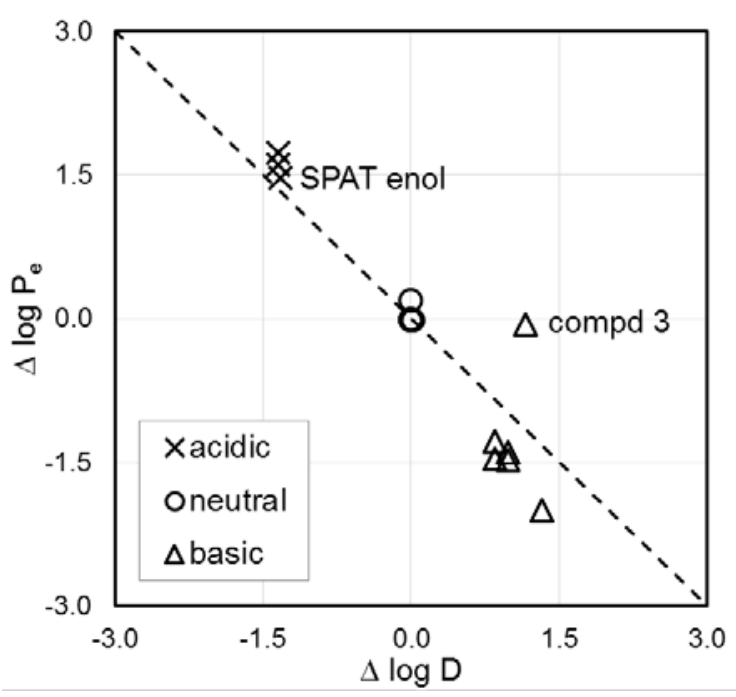

Figure 4. 


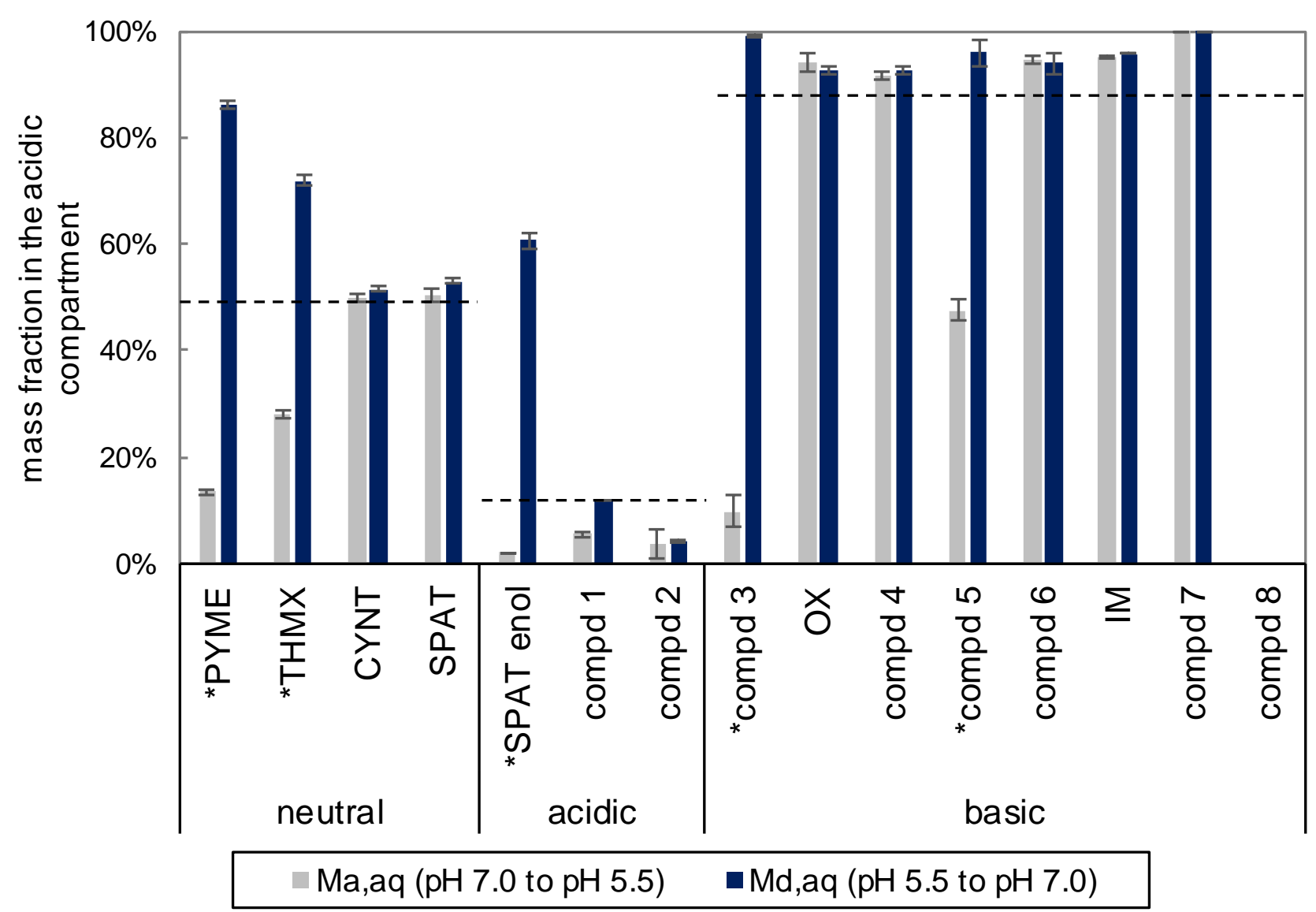

Figure 5. 
A

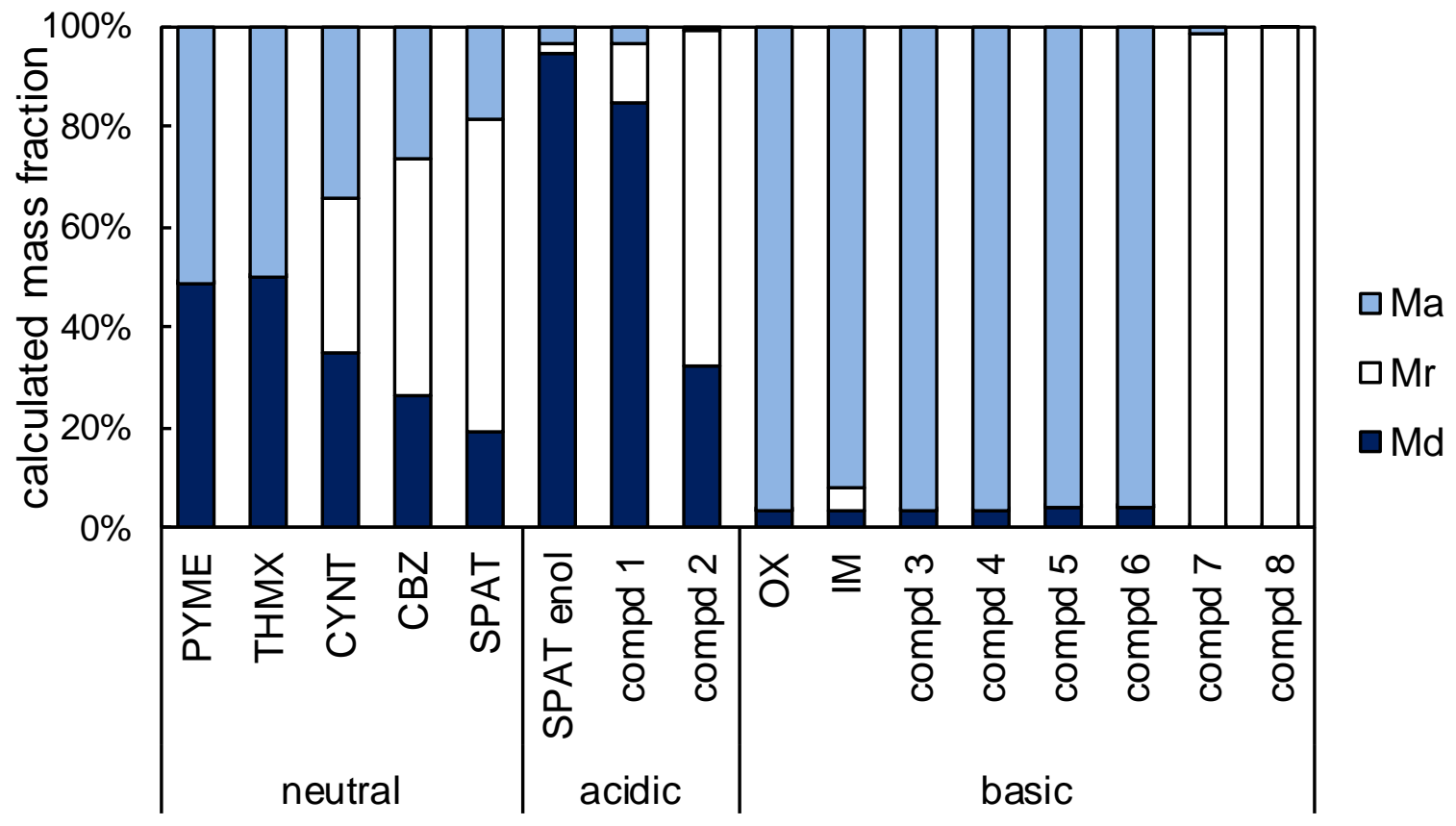

B

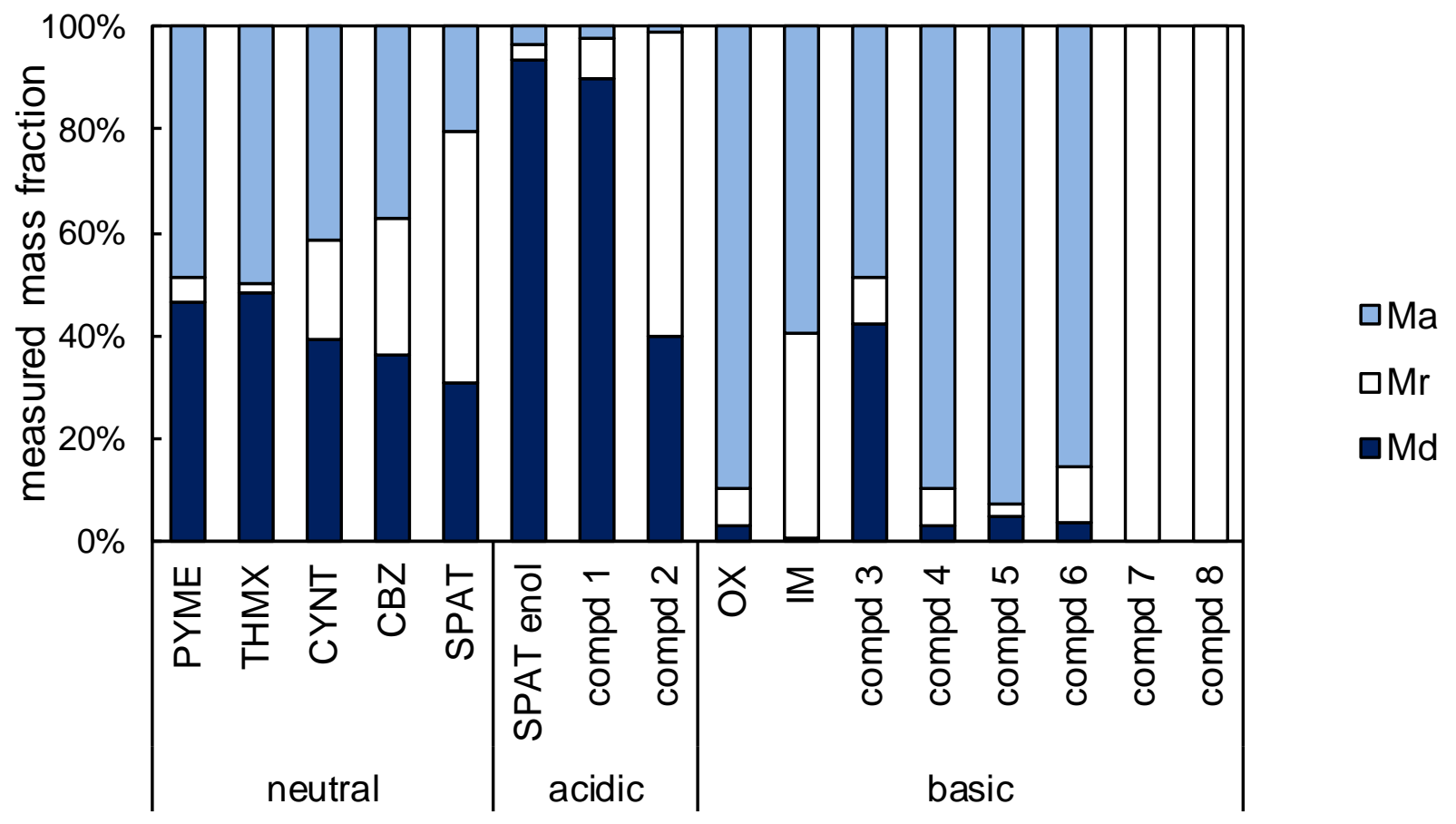

Figure 6. 
A

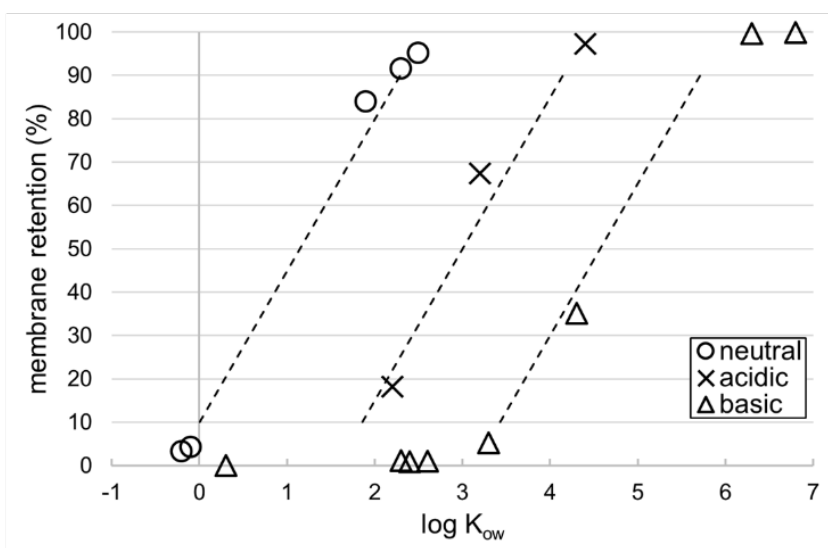

B

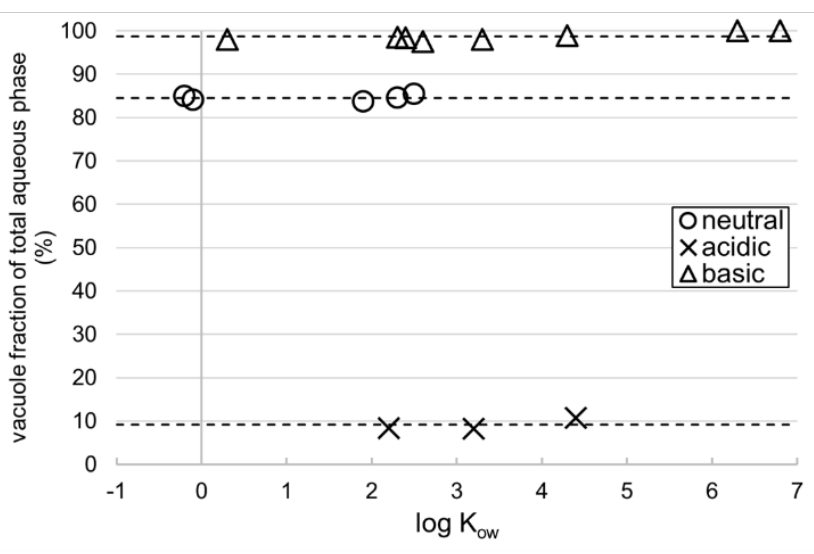

654

$655 \quad$ Figure 7.

656 
658

659

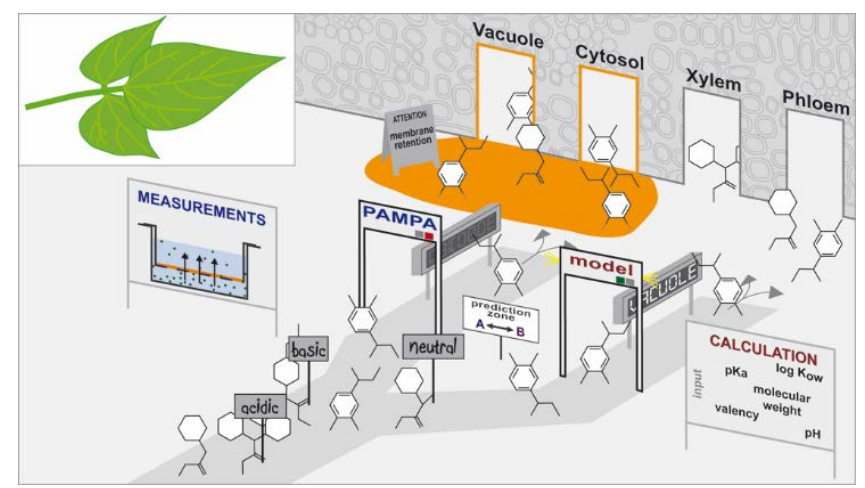

660

661 